\title{
The organ donation knowledge: an observational study among students and general population from Acquaviva delle Fonti, Bari, in Southern Italy
}

\author{
Elsa Vitale, ${ }^{1}$ Vittorio Guglielmi, ${ }^{2}$ Federica Sardano, ${ }^{3}$ Francesco Germini ${ }^{4}$ \\ ${ }^{1}$ Department of Mental Health, ASL Bari; ${ }^{2}$ Miulli Hospital, Acquaviva delle Fonti, Bari; ${ }^{3}$ Nursing Course of University of \\ Bari; ${ }^{4}$ Direction of Nursing Profession, ASL Bari, Italy
}

\begin{abstract}
For numerous patients suffering from pathologies that irreversibly damage organs and tissues, transplantation is the best therapeutic solution, and in several cases the only possible one. In this context the present study has set the objective to analyze the attitude of the respondents towards donation in relation to their education levels. A questionnaire was elaborated and administered. A range Linkert-score was associated with each question indicating as 0 the minimum preference and 5 the maximum preference. For each question participants had to indicate a single answer among proposals. $\mathrm{X}^{2}$ test among answers collected was assessed in order to statistically verify the significance between answers given by the two groups as regards organs donation. The recruited group was made up of 203 students of which 129 were girls (64\%) and 74 were boys (36\%). The youngest student was aged 17 and the oldest 21 , mean age was $18.58 \pm 1.89$ years. The population group considered in this study consisted of 203 subjects, of which $117(58 \%)$ females and $86(42 \%)$ males. The youngest person interviewed belonging to population group was aged 22 and the oldest was 87 years old, the mean age was $51.03 \pm 14.02$ years. Our study revealed the attitude towards donation with a greater degree of consensus that has been demonstrated within the population rather than within students.
\end{abstract}

\section{Introduction}

For numerous patients suffering from pathologies that irreversibly damage organs and tissues, transplantation is the best therapeutic solution, and in several cases the only possible one. In fact, according to recent data published by the World Health Organization (WHO) Global Observatory on Organ Donation and Transplantation, more than 100,000 organ transplants are performed each year worldwide. ${ }^{1}$ However, the scarcity of cadaver organs and tissues continues to be

Correspondence: Elsa Vitale, Department of Mental Health, ASL Bari, Via X Marzo 43, Modugno (BA), Italy.

E-mail: vitaleelsa@libero.it

Key words: Culture; organ donation; transplantation.

Conflict of interests: the authors declare no conflict of interests.

Received for publication: 5 December 2019.

Revision received: 5 February 2020.

Accepted for publication: 27 February 2020.

This work is licensed under a Creative Commons Attribution NonCommercial 4.0 License (CC BY-NC 4.0).

${ }^{\circ}$ Copyright: the Author(s), 2020

Licensee PAGEPress, Italy

Italian Journal of Medicine 2020; 14:49-54

doi:10.4081/itjm.2020.1245 the main obstacle to a complete transplant development and constitutes an insurmountable barrier to generalize this therapy. Although transplants save thousands of lives and transform the quality of life of thousands of patients: many patients die or continue to receive replacement treatment for chronic renal failure because the supply of organs for transplantation does not cover current needs. A country, region or hospital can have a large healthcare infrastructure and be equipped with high technology and with qualified and trained professionals to carry out any type of transplant, but if it does not have an adequate system for identifying donors, it cannot have organs at disposal to be transplanted to patients. It could be said that the transplant palace is like an inverted pyramid that can only be sustained thanks to the existence of donors. This concept is perfectly summarized by the phrase Sin donante no hay transplante, as: without a donor there is no transplant. ${ }^{2}$

In October 2010, after almost ten years from the introduction of the Law 91/1999 governing the declaration of intention to donate organs, the Italian Organ Donors Association (AIDO), in its provincial section of Monza and Brianza, conducted a survey on a sample of 373 subjects distinguished by gender and by 6 age classes, the aim was to learn about the attitude and opinions of the population towards post-mortem organ donation, as it can influence their behavior and consequently direct the decision to consent or not to donate organs in a concrete situation. 324 out of 373 
respondents declared themselves for organ and tissue donation (86.9\%), 11 against, 35 indifferent and 3 did not respond. Between women and men, as well as in the age groups, there were no differences, instead according to the different levels of education of the interviewees we noted that among graduates $97 \%$, declared themselves for donation and only $2.1 \%$ was indifferent. The percentage decreased if we specifically asked for the donation of their own organs: the availability dropped from $86.4 \%$ to $74.0 \%$, without obvious differences in age groups, schooling or gender of the interviewees. As for the reasons that justify the favorable attitude towards organ donation: $40.10 \%$ believe that organ donation is a way to avoid wasting opportunities for others; $40.40 \%$ consider the donation an act of solidarity; $8.80 \%$ consider it a civil duty; $5.7 \%$ consider it a victory of life over death; $1.80 \%$ consider it a means to prevent an illegal trade from starting due to lack of organs. Instead, among the reasons that justify an attitude contrary to the donation: $12.3 \%$ declared themselves opposed/indifferent to the donation and $9.0 \%$ of them believed that the body has value even after death; $63.60 \%$ answered that the threshold that separates being alive from being dead is not sure; $18.20 \%$ answered that the donation is difficult to control and can be lent to speculation; $4.70 \%$ said that the donation is contrary to their religious belief. Concerning the possibility of opposing a family member's donation of organs, despite his/her consent to the donation, only $8 \%$ of the respondents agreed to the possibility of opposing, while $85.5 \%$ was against, $3.8 \%$ were hesitant and $2.7 \%$ did not respond. The last question of the survey asked about the actions to be taken to encourage greater organ donations for therapeutic transplantation: $33.1 \%$ asked to provide more information about it, $19.2 \%$ to adapt the legislation, $17 \%$ to increase dedicated staff for withdrawals, transplants and equipment, $17.7 \%$ did not respond and the remainder was directed towards other reasons. ${ }^{3}$

From data collected by AIDO it is clear that there is an initial positive emotional predisposition to organ donation and a reduced opposition rate that fades when the interviewee is confronted with a choice of personal donation. The answers that denote an indifferent attitude towards the topic of organ donation lead to consider the importance and indispensability of a continuous work aimed at raising citizens awareness through information and education, since they shall always be considered as the main protagonists in the donation process and organ transplantation. It is necessary to speak, inform, and educate on donation in order to grow the culture of gift, as well as to work more on the indifferent person than on the contrary one., ${ }^{4,5}$

The low donation rate in Puglia, as shown by data provided by the Regional Transplant Center of the Policlinic in Bari, represented an excellent starting point to verify the level of knowledge and information about the topic and to offer an initial point of awareness on the culture of 'gift'. The low number of donations is in fact due, rather than to a state of ignorance, to a disinformation on all the multiple levels that form the great pyramid of transplants.

In this context the present study has set the objective to analyze the attitude of the respondents towards donation in relation to their education levels.

\section{Materials and Methods}

The study was carried out between April and September 2019. After a careful analysis of the literature, two population groups were taken into consideration: students and adults, in order to test their organ donation knowledge. All participants involved in this study lived or attended their studies in the Acquaviva delle Fonti, Bari, in Southern Italy.

The student group included young people aged between 17 and 21 who attended different higher education institutions, as: high school, technical school and professional school. On the other hand, the adult group included people aged from 21 to 87.

Students were interviewed in April 2018 during lessons. Firstly, students' consents to participate in this survey were collected. Then, all students who agreed to participate in this study were invited to answer to the questionnaire.

General population was met in pharmacies and surgeries present in Acquaviva delle Fonti, Bari, in order to facilitate people recruitment for the study. All general population voluntarily agreed to participate and answer the same questionnaire.

The questionnaire was elaborated $a d$ hoc and included 15 multiple choice questions, which assessed the donator culture as regards organs donation. For questions from number 1 to 12 and number 15 a range Linkert-score as preference grading from 0 to 5 was assessed, indicating as 0 the minimum preference and 5 the maximum preference among the answers given. Furthermore, question number 13 and 14 indicated specifically where interviewers acquired information on the donation topic and what specific type of information they would have wanted to receive, respectively. For each question participants had to indicate a single answer between proposals. The questionnaire administered was elaborated into 6 sections. Specifically, the first and the second part explored personal and employment data, respectively, including 5 items, which collected general information on the interviewers, such as: age, sex, educational level as 5th grade, middle school, high school diploma, degree. Moreover, professional data were divided for the student group according to their educational track, while and for the general population according to the type of job 
employee, freelancer, manager and health worker. Finally, the demographic section explored also the religious faith, simply indicating if Catholic or other. The third section of the questionnaire explored the attitude towards donation, particularly: the degree of consent to organ, tissue and cell transplantation as a donor, the degree of consent to any family organ donation and the degree of importance on family discussions on consent to donation. The fourth part of the questionnaire illustrated knowledge about the subject. This part was found to be the most substantial in the questionnaire, in fact it was made up of 8 questions that have made it possible to obtain information about the wealth of knowledge regarding organ, cell and tissue donation. The extent of the candidate awareness was analyzed by covering the following topics: i) when does organ donation take place?; ii) the possibility of deciding in life to whom your organs will be donated; iii) the possibility for donor's family members to know the identity of the recipient, iv) the position of the Catholic Church regarding organ donation; v) the possibility of living donation; vi) the modalities of expression of the will in life for the donation. In this section answers did not appear as preference grading from 0 to 5 , as they were collected in such a way to illustrate the interviewers belief in the organ donation information. The fifth part of the questionnaire included the degree of information on donation, such as to what extent the candidate believes he/she is informed about the donation of organs, tissues and cells; expectations regarding the information on donation, such as: where or by whom information about the donation can be found, the type of information about it. Finally, the sixth section of the questionnaire included the level of awareness, as the candidate was placed in the condition of needing an organ more than he/she had to donate it, and the position was analyzed.

Statistical analyses were performed using IBM SPSS 20 software. Population characteristics were assessed by the percentage distribution of qualitative variable prevalence.

All the answers received were assessed as distribution curves performing the Shapiro-Wilk and Kolmogorov-Smirnov tests. As the distributions of the variables analyzed did not conform to Gaussian distribution, intra-group comparisons were assessed using the $\mathrm{X}^{2}$ test. The threshold for probability of erroneous rejection of the null hypothesis $\mathrm{H}_{0}$ which is in fact not equal was assessed at 0.05 .

\section{Results}

Student sample included 203 students aged between 17 and 21, belonging to the following schools: Don Milani High School ( $\mathrm{No}=98)$, C. Colamonico Technical Institute $(\mathrm{No}=61)$ and $N$. Chiarulli Profes- sional Institute $(\mathrm{No}=50)$, located in Acquaviva delle Fonti (Ba). 129 students were girls (64\%) and 74 were boys $(36 \%)$. The youngest student was aged 17 and the oldest 21 , mean age was $18.58 \pm 1.89$ years.

$45 \%$ of students attended high school, $30 \%$ attended technical courses and $25 \%$ professional tracks. $22 \%$ of total students had a Catholic belief. The remaining $78 \%$ had a different creed than the latter.

General population included 203 persons randomly collected, in Acquaviva delle Fonti (BA), specifically at pharmacies and surgeries, respectively. These places were chosen in order to facilitate general population recruitment.

The population group considered in this study consisted of 203 subjects, of which 117 (58\%) female and $86(42 \%)$ male. The youngest person interviewed belonging to population group was aged 22 and the oldest was aged 87 , mean age was $51.03 \pm 14.02$ years. $96 \%$ of total population had a Catholic belief. The remaining $4 \%$ had a different creed. $28 \%$ of the population group worked as employee, $25 \%$ as freelancer, $1 \%$ as manager, $21 \%$ as health worker, and $10 \%$ was retired.

To verify the hypothesis that organ donation knowledge differs based on socio condition as student or not, the $\mathrm{X}^{2}$ test among answers collected was assessed. The results of comparison between students and general population are shown in Table 1 .

Analyses showed a statistically significant difference $(\mathrm{P}<0.05)$ in the all answers given, except for questions number 1 and number 10 . In the first question participants were asked if they were in favor or against cell and organ donation. Students answered that they were more in favor than the general population. However, this difference was not statistically significant. The other question in which difference was not statistically significant was number 10 , where participants were asked if they knew the possibility of donation from living donors. Most of them, both belonging to student or general population group did not know about this possibility.

As regards question number 13 , it was asked where interviewers acquired information on the donation topic. $29 \%$ of students answered that they liked to receive more information on the donation topic from training events, $8 \%$ of them from advertising, $11 \%$ of them from daily articles and magazines, $13 \%$ from television, and 39\% from the Internet. While the general population group answered that they preferred to receive more information on the donation topic from training events (36\%), 11\% from advertising, $6 \%$ from daily articles and magazines, $21 \%$ from television and finally, 26\% from the Internet.

Concerning question number 14, participants were asked what specific information they would have liked to receive from the resources cited in answer number $13.13 \%$ of students answered that they 
Table 1. Comparison of organ donation knowledge between students and general population.

\begin{tabular}{|c|c|c|c|c|c|c|}
\hline Question & $\begin{array}{l}\text { Answer } 1 \\
\text { Very }\end{array}$ & $\begin{array}{l}\text { Answer } 2 \\
\text { Quite }\end{array}$ & $\begin{array}{l}\text { Answer } 3 \\
\text { Undecided }\end{array}$ & $\begin{array}{l}\text { Answer } 4 \\
\text { Little }\end{array}$ & $\begin{array}{l}\text { Answer } 5 \\
\text { In no way }\end{array}$ & $X^{2}$ test \\
\hline $\begin{array}{l}\text { 1. Based on your knowledge: } \\
\text { are you in favor of organ, } \\
\text { cell and tissue } \\
\text { transplantation as a donor? }\end{array}$ & $\begin{array}{l}\text { Students } \\
(\mathrm{No}=3) 1.5 \% \\
\text { Population } \\
(\mathrm{No}=3) 1.5 \%\end{array}$ & $\begin{array}{l}\text { Students } \\
(\mathrm{No}=5) 2.5 \% \\
\text { Population } \\
(\mathrm{No}=6) 3 \%\end{array}$ & $\begin{array}{l}\text { Students } \\
(\mathrm{No}=16) 7.9 \% \\
\text { Population } \\
(\mathrm{No}=25) 12.3 \%\end{array}$ & $\begin{array}{l}\text { Students } \\
(\mathrm{No}=92) 43.5 \% \\
\text { Population } \\
(\mathrm{No}=66) 32.5 \%\end{array}$ & $\begin{array}{l}\text { Students } \\
(\mathrm{No}=103) 50.7 \% \\
\text { Population } \\
(\mathrm{No}=87) 42.9 \%\end{array}$ & $X^{2}=0.104$ \\
\hline $\begin{array}{l}\text { 2. Would you be in favor of any } \\
\text { family organ donation? }\end{array}$ & $\begin{array}{l}\text { Students } \\
(\mathrm{No}=2) 1 \% \\
\text { Population } \\
(\mathrm{No}=5) 2.5 \%\end{array}$ & $\begin{array}{l}\text { Students } \\
(\mathrm{No}=5) 2.5 \% \\
\text { Population } \\
(\mathrm{No}=15) 7.4 \%\end{array}$ & $\begin{array}{l}\text { Students } \\
(\mathrm{No}=40) 19.7 \% \\
\text { Population } \\
(\mathrm{No}=40) 19.7 \%\end{array}$ & $\begin{array}{l}\text { Students } \\
(\mathrm{No}=86) 42.4 \% \\
\text { Population } \\
(\mathrm{No}=54) 26.6 \%\end{array}$ & $\begin{array}{l}\text { Students } \\
(\mathrm{No}=70) 34.5 \% \\
\text { Population } \\
(\mathrm{No}=89) 43.8 \%\end{array}$ & $X^{2}=0.003 *$ \\
\hline $\begin{array}{l}\text { 3. Do you know how organ } \\
\text { donation occurs precisely? }\end{array}$ & $\begin{array}{l}\text { Students } \\
(\mathrm{No}=0) 0 \% \\
\text { Population } \\
(\mathrm{No}=0) 0 \%\end{array}$ & $\begin{array}{l}\text { Students } \\
(\mathrm{No}=67) 33 \% \\
\text { Population } \\
(\mathrm{No}=24) 11.8 \%\end{array}$ & $\begin{array}{l}\text { Students } \\
(\mathrm{No}=74) 36.5 \% \\
\text { Population } \\
(\mathrm{No}=71) 35 \%\end{array}$ & $\begin{array}{l}\text { Students } \\
(\mathrm{No}=54) 26.6 \% \\
\text { Population } \\
(\mathrm{No}=93) 45.8 \%\end{array}$ & $\begin{array}{l}\text { Students } \\
(\mathrm{No}=8) 3.9 \% \\
\text { Population } \\
(\mathrm{No}=15) 7.4 \%\end{array}$ & $\mathrm{X}^{2}=0.000^{*}$ \\
\hline $\begin{array}{l}\text { 4. How much do you know } \\
\text { bout brain death? }\end{array}$ & $\begin{array}{l}\text { Students } \\
(\mathrm{No}=0) 0 \% \\
\text { Population } \\
(\mathrm{No}=0) 0 \%\end{array}$ & $\begin{array}{l}\text { Students } \\
(\mathrm{No}=10) 4.9 \% \\
\text { Population } \\
(\mathrm{No}=32) 15.8 \%\end{array}$ & $\begin{array}{l}\text { Students } \\
(\mathrm{No}=9) 4.4 \% \\
\text { Population } \\
(\mathrm{No}=1) 0.5 \%\end{array}$ & $\begin{array}{l}\text { Students } \\
\mathrm{s}(\mathrm{No}=19) 9.4 \% \\
\text { Population } \\
(\mathrm{No}=12) 5.9 \%\end{array}$ & $\begin{array}{l}\text { Students } \\
(\mathrm{No}=165) 81.3 \% \\
\text { Population } \\
(\mathrm{No}=158) 77.8 \%\end{array}$ & $\mathrm{X}^{2}=0.000^{*}$ \\
\hline $\begin{array}{l}\text { 5. How far can you distinguish } \\
\text { the concept of brain death } \\
\text { from that of coma? }\end{array}$ & $\begin{array}{l}\text { Students } \\
(\mathrm{No}=0) 0 \% \\
\text { Population } \\
(\mathrm{No}=0) 0 \%\end{array}$ & $\begin{array}{l}\text { Students } \\
(\mathrm{No}=17) 8.4 \% \\
\text { Population } \\
(\mathrm{No}=29) 14.3 \%\end{array}$ & $\begin{array}{l}\text { Students } \\
(\mathrm{No}=2) 1 \% \\
\text { Population } \\
(\mathrm{No}=2) 1 \%\end{array}$ & $\begin{array}{l}\text { Students } \\
(\mathrm{No}=178) 87.7 \% \\
\text { Population } \\
(\mathrm{No}=156) 76.8 \%\end{array}$ & $\begin{array}{l}\text { Students } \\
(\mathrm{No}=6) 3 \% \\
\text { Population } \\
(\mathrm{No}=16) 7.9 \%\end{array}$ & $\mathrm{X}^{2}=0.028^{*}$ \\
\hline $\begin{array}{l}\text { 6. How important do you think } \\
\text { it is to discuss about the } \\
\text { consent to organ donation } \\
\text { after death in the family? }\end{array}$ & $\begin{array}{l}\text { Students } \\
(\mathrm{No}=0) 0 \% \\
\text { Population } \\
(\mathrm{No}=0) 0 \%\end{array}$ & $\begin{array}{l}\text { Students } \\
(\mathrm{No}=3) 1.5 \% \\
\text { Population } \\
(\mathrm{No}=8) 3.9 \%\end{array}$ & $\begin{array}{l}\text { Students } \\
(\mathrm{No}=9) 4.4 \% \\
\text { Population } \\
(\mathrm{No}=8) 3.9 \%\end{array}$ & $\begin{array}{l}\text { Students } \\
(\mathrm{No}=35) 17.2 \% \\
\text { Population } \\
(\mathrm{No}=12) 5.9 \%\end{array}$ & $\begin{array}{l}\text { Students } \\
(\mathrm{No}=156) 76.8 \% \\
\text { Population } \\
(\mathrm{No}=175) 86.2 \%\end{array}$ & $\mathrm{X}^{2}=0.002 *$ \\
\hline $\begin{array}{l}\text { 7. How much do you know } \\
\text { about the possibility of } \\
\text { deciding in life to whom } \\
\text { your organs will be donated? }\end{array}$ & $\begin{array}{l}\text { Students } \\
(\mathrm{No}=0) 0 \% \\
\text { Population } \\
(\mathrm{No}=0) 0 \%\end{array}$ & $\begin{array}{l}\text { Students } \\
(\mathrm{No}=44) 21.7 \% \\
\text { Population } \\
(\mathrm{No}=20) 9.9 \%\end{array}$ & $\begin{array}{l}\text { Students } \\
(\mathrm{No}=34) 16.7 \% \\
\text { Population } \\
(\mathrm{No}=14) 6.9 \%\end{array}$ & $\begin{array}{l}\text { Students } \\
(\mathrm{No}=16) 7.9 \% \\
\text { Population } \\
(\mathrm{No}=17) 8.4 \%\end{array}$ & $\begin{array}{l}\text { Students } \\
(\mathrm{No}=109) 53.7 \% \\
\text { Population } \\
(\mathrm{No}=152) 74.9 \%\end{array}$ & $\mathrm{X}^{2}=0.000^{*}$ \\
\hline $\begin{array}{l}\text { 8. How much do you know } \\
\text { about the donor's family } \\
\text { members ability to know the } \\
\text { recipient's identity? }\end{array}$ & $\begin{array}{l}\text { Students } \\
(\mathrm{No}=0) 0 \% \\
\text { Population } \\
(\mathrm{No}=0) 0 \%\end{array}$ & $\begin{array}{l}\text { Students } \\
(\mathrm{No}=38) 18.7 \% \\
\text { Population } \\
(\mathrm{No}=21) 10.3 \%\end{array}$ & $\begin{array}{l}\text { Students } \\
(\mathrm{No}=60) 29.6 \% \\
\text { Population } \\
(\mathrm{No}=39) 19.2 \%\end{array}$ & $\begin{array}{l}\text { Students } \\
(\mathrm{No}=55) 27.1 \% \\
\text { Population } \\
(\mathrm{No}=37) 18.2 \%\end{array}$ & $\begin{array}{l}\text { Students } \\
(\mathrm{No}=50) 24.6 \% \\
\text { Population } \\
(\mathrm{No}=106) 52.2 \%\end{array}$ & $\mathrm{X}^{2}=0.000^{*}$ \\
\hline $\begin{array}{l}\text { 9. Do you think the Catholic } \\
\text { Church is in favor of organ } \\
\text { donation? }\end{array}$ & $\begin{array}{l}\text { Students } \\
(\mathrm{No}=2) 1 \% \\
\text { Population } \\
(\mathrm{No}=0) 0 \%\end{array}$ & $\begin{array}{l}\text { Students } \\
(\mathrm{No}=99) 48.8 \% \\
\text { Population } \\
(\mathrm{No}=81) 39.9 \%\end{array}$ & $\begin{array}{l}\text { Students } \\
(\mathrm{No}=31) 15.3 \% \\
\text { Population } \\
(\mathrm{No}=16) 7.9 \%\end{array}$ & $\begin{array}{l}\text { Students } \\
(\mathrm{No}=60) 29.6 \% \\
\text { Population } \\
(\mathrm{No}=14) 6.9 \%\end{array}$ & $\begin{array}{l}\text { Students } \\
(\mathrm{No}=11) 5.4 \% \\
\text { Population } \\
(\mathrm{No}=92) 45.3 \%\end{array}$ & $\mathrm{X}^{2}=0.000^{*}$ \\
\hline $\begin{array}{l}\text { 10. How much do you know } \\
\text { about the possibility of } \\
\text { donation from living donors? }\end{array}$ & $\begin{array}{l}\text { Students } \\
(\mathrm{No}=0) 0 \% \\
\text { Population } \\
(\mathrm{No}=0) 0 \%\end{array}$ & $\begin{array}{l}\text { Students } \\
(\mathrm{No}=33) 16.3 \% \\
\text { Population } \\
(\mathrm{No}=29) 14.3 \%\end{array}$ & $\begin{array}{l}\text { Students } \\
(\mathrm{No}=1) 0.5 \% \\
\text { Population } \\
(\mathrm{No}=6) 3 \%\end{array}$ & $\begin{array}{l}\text { Students } \\
(\mathrm{No}=20) 9.9 \% \\
\text { Population } \\
(\mathrm{No}=10) 4.9 \%\end{array}$ & $\begin{array}{l}\text { Students } \\
(\mathrm{No}=149) 73.4 \% \\
\text { Population } \\
(\mathrm{No}=158) 77.8 \%\end{array}$ & $X^{2}=0.059$ \\
\hline $\begin{array}{l}\text { 11. How much are you aware } \\
\text { of the mode of expression } \\
\text { of will in life for the donation } \\
\text { of your organs and tissues? }\end{array}$ & $\begin{array}{l}\text { Students } \\
(\mathrm{No}=0) 0 \% \\
\text { Population } \\
(\mathrm{No}=0) 0 \%\end{array}$ & $\begin{array}{l}\text { Students } \\
(\mathrm{No}=70) 34.5 \% \\
\text { Population } \\
(\mathrm{No}=62) 30.5 \%\end{array}$ & $\begin{array}{l}\text { Students } \\
(\mathrm{No}=8) 3.9 \% \\
\text { Population } \\
(\mathrm{No}=3) 1.5 \%\end{array}$ & $\begin{array}{l}\text { Students } \\
(\mathrm{No}=114) 56.2 \% \\
\text { Population } \\
(\mathrm{No}=113) 55.7 \%\end{array}$ & $\begin{array}{l}\text { Students } \\
(\mathrm{No}=11) 5.4 \% \\
\text { Population } \\
(\mathrm{No}=25) 12.3 \%\end{array}$ & $\mathrm{X}^{2}=0.042 *$ \\
\hline $\begin{array}{l}\text { 12. Do you think you are } \\
\text { informed about organ, tissue } \\
\text { and cell donation? }\end{array}$ & $\begin{array}{l}\text { Students } \\
(\mathrm{No}=3) 1.5 \% \\
\text { Population } \\
(\mathrm{No}=7) 3.4 \%\end{array}$ & $\begin{array}{l}\text { Students } \\
(\mathrm{No}=11) 5.4 \% \\
\text { Population } \\
(\mathrm{No}=11) 5.4 \%\end{array}$ & $\begin{array}{l}\text { Students } \\
(\mathrm{No}=154) 75.9 \% \\
\text { Population } \\
(\mathrm{No}=106) 52.2 \%\end{array}$ & $\begin{array}{l}\text { Students } \\
(\mathrm{No}=31) 15.3 \% \\
\text { Population } \\
(\mathrm{No}=60) 29.6 \%\end{array}$ & $\begin{array}{l}\text { Students } \\
(\mathrm{No}=4) 2 \% \\
\text { Population } \\
(\mathrm{No}=19) 9.4 \%\end{array}$ & $\mathrm{X}^{2}=0.000^{*}$ \\
\hline $\begin{array}{l}\text { 15. Each of us has been found } \\
\text { to be much more likely } \\
\text { to need an organ than } \\
\text { to donate an organ. Based on } \\
\text { this statement, how do you } \\
\text { deal with the donation? }\end{array}$ & $\begin{array}{l}\text { Students } \\
(\mathrm{No}=5) 2.5 \% \\
\text { Population } \\
(\mathrm{No}=2) 1 \%\end{array}$ & $\begin{array}{l}\text { Students } \\
(\mathrm{No}=7) 3.4 \% \\
\text { Population } \\
(\mathrm{No}=1) 0.5 \%\end{array}$ & $\begin{array}{l}\text { Students } \\
(\mathrm{No}=89) 43.8 \% \\
\text { Population } \\
(\mathrm{No}=68) 33.5 \%\end{array}$ & $\begin{array}{l}\text { Students } \\
(\mathrm{No}=63) 31 \% \\
\text { Population } \\
(\mathrm{No}=65) 32 \%\end{array}$ & $\begin{array}{l}\text { Students } \\
(\mathrm{No}=39) 19.2 \% \\
\text { Population } \\
(\mathrm{No}=67) 33 \%\end{array}$ & $\mathrm{X}^{2}=0.003 *$ \\
\hline
\end{tabular}

${ }^{*} \mathrm{P}$ value $<0.05$ statistically significant. 
liked to receive more information on death ascertainment, $19 \%$ preferred to receive more information on physical and age limits for donation; $7 \%$ agreed to receive information on how to return the body; $16 \%$ liked to receive more information on how organs were assigned; finally $45 \%$ of students agreed to receive more information on donation process. On the other hand, the general population group answered as follows: $16 \%$ of persons answered that they liked to receive more information on death ascertainment, $14 \%$ preferred to receive more information on physical and age limits for donation; $17 \%$ agreed to receive information on how to return the body; $13 \%$ liked to receive more information on how organs were assigned; finally $40 \%$ of general population agreed to receive more information on donation process.

\section{Discussion and Conclusions}

The study that inspired us to collect information on the field of transplant knowledge was the one carried out by the Regional Transplant Center in collaboration with the Association of Donors of Organs of Friuli Venezia Giulia (FVG ADO) which structured a questionnaire aimed at testing the knowledge among the population (adults and students) on organ donation. ${ }^{6} \mathrm{~A}$ total of 1,200 questionnaires were administered, of which $59 \%$ were completed by adult subjects and $41 \%$ were completed by students (of whom $30 \%$ went to middle schools, $57.2 \%$ went to high school and the remaining $12.8 \%$ attended the University). Seven questions were asked, as: i) when organ donation occurs; ii) what is brain death; iii) what is the difference between brain death and coma; iv) the importance of discussing the topic of organ donation in the family; v) if they could decide: to whom they would like their organs to be donated in life; vi) how the main religions dealt with the issue of organ donation; and vii) if it is possible for the family members of the donor to know the identity of the person who received the organs.

Our questionnaire included the same type of questions, highlighting any significant differences between the group of students and that of the general population. It was interesting to note that, for many questions, the two groups claimed that they did not have much knowledge of. In fact, from question 3 to question 8 no participant, belonging to one of the two groups, claimed to have complete knowledge of the requested topic. These data showed that the two groups considered, regardless of whether they were students or not, possessed a level of knowledge of organ donation that varied from moderate to insufficient. This level of knowledge tested was in agreement with the study mentioned above.
Concerning question number 9, asking if the Catholic Church was in favor or against organ donation, most students $(48.8 \%)$ and general population (39.9\%) answered 'quite'. In particular, most of students answered 'quite', while the majority of general population answered 'quite' and 'in no way'. Data were in agreement with the religious creed declared, since $96 \%$ of the general population was catholic and also $22 \%$ of students. These data were in agreement with the Sung et al. study ${ }^{7}$ in which the effects of religious characteristics and belief levels on the relationship between religion and organ donation were analyzed. Results showed that Christianity, such as Catholicism and Protestantism, positively affects the willingness to donate organs as compared with Buddhism. Religiosity level also exerted an interaction effect that strengthened the relationship between Christianity and willingness to donate organs.

Additionally, we tried to focus the attention on a theme that, in contemporary bioethical reflection, is hardly considered. As a result of this, the need to give continuity to the training events emerges. Such events that are carried out primarily in schools, where major gaps were noted, shall also be made available for all citizens, in order to facilitate the dissemination of information. Dissemination may take place through the most modern means of communication (for example the Internet and social media) that are easily accessible to young people, or through television, that represents a medium commonly used by older age groups. Information and training events would surely produce positive results, as they would be useful in bringing out doubts, or in encouraging a constructive debate based on the comparison between users and experienced professionals on these issues. In-depth tools could be provided, such as dedicated websites and ad-hoc information material. Before developing all this, it would be necessary at least to inform and train health personnel in general.

In fact, the continuous and rapid changes affecting the healthcare world require trainers to direct professionals towards a type of learning that could allow them to cope with such changes and to favor the development of an advanced health service even outside the hospital environment. The achievement of these objectives is closely related to the quality of health education and training; which is a collective responsibility. First of all, it must involve the academic community, since planning and delivering training require primarily an active participation of medical schools, programs and regulation of professional profiles (enrollment, certifications, licenses). ${ }^{7-10}$ The issues to be addressed are essentially two: the basic training of health professionals and the constant maintenance of up-to-date training with respect to knowledge that is constantly changing. Only in this way, 
starting from the fundamentals, it is possible to provide first the information needed and then to carry out the training within the community so as to promote the culture of donation and then give the best of us. ${ }^{11}$

Our study revealed the attitude towards donation, a greater degree of consensus has been demonstrated within the population rather than among students..$^{12,13}$ In this case, it can be emphasized how crucial is the role of culture within the entire donation process, understood as open-mindedness. ${ }^{14,15}$

According to data collected, we can easily outline an overview of the general situation which shows a low level of information at all levels, especially among students, who declare to be poorly informed about the topic. The level of disinformation on donations remains high without considering the education level. The methods that both students and population samples deemed to be the most appropriate to carry out a culture of donations are information events, followed by the Internet and television. ${ }^{16,17}$

Certainly, the low number of the two samples will not make our study enough representative, but in any case, it aimed to photograph the knowledge level possessed by the general population and by the students. In reality, a future development of this study could involve the inclusion of more participants, perhaps from different areas, with a multicenter character, so as to observe the level of knowledge of the issue of organ donation in different parts of Italy. In this study, instead, the town of Acquaviva delle Fonti, in the province of Bari, was considered only for the sake of the experimenter's convenience in collecting data.

In literature many works deal mainly with the level of knowledge that healthcare professionals, medical students or nurses have about the donation of organs. However, only few studies deal with the issue of organ donation aimed at the general population, whether they are students or not. ${ }^{18,19}$

In any case, our study highlighted a statistically significant difference between the responses received from the two groups, both in terms of the basic knowledge possessed and the beliefs about the topics covered.

\section{References}

1. Fonte Sistema Informativo Trapianti. [Internet]; 2019 Available from: https://rapianti.sanita.it/statistiche/attivita Accessed: 19 August 2019.

2. Legge 29 dicembre 1993 n 578, Gazzetta Ufficiale 8 gennaio 1994. "Norme per l'accertamento e la documentazione di morte", Art 2. [Internet]; 1994. Available from: https://www.issalute.it Accessed: 18 August 2019.

3. Zampieron A, Corso M, Frigo AC. Undergraduate nursing students' attitudes towards organ donation: a survey in an Italian university. Int Nurs Rev 2010;57:370-6.

4. Ministero della Salute, Centro Nazionale Trapianti. Donazioni e trapianti, i dati 2018. [Internet]; 2018.
Available from: http://www.trapianti.salute.gov.it/trapianti/ Accessed: 19 August 2019.

5. Legge 1 Aprile 1999 n. 91. "Disposizioni in materia di prelievi e di trapianti di organi e di tessuti", Art 23. Gazzetta Ufficiale n. 87, 15 Aprile 1999. [Internet] 1991. Available from: http://www.parlamento.it/parlam/leggi/ 990911.htm Accessed: 20 August 2019.

6. Manuale TPM. Organ donation and transplantation activities 2009. Global Observatory on Donation and Transplantation. [Internet]; 2009. Available from: www.transplantobservatory.org/Pages/DataReports Accessed: 19 March 2019.

7. Giordano F, Fiorillo F, Benedetti V. Questionario su dono e trapianto rivolto alla popolazione. [Internet]; Available from: http://www.adofvg.it/documenti/Articolo_per_sito_ADO_su_questionario.pdf Accessed: 19 March 2019.

8. Sung Y. Interaction Effects of Religiosity Level on the Relationship between Religion and Willingness to Donate Organs. Religions 2018;8:1-10.

9. Weiss J, Shaw D, Schober R, et al.; Comité National du Don d'Organes Cndo. Attitudes towards organ donation and relation to wish to donate posthumously. Swiss Med Wkly 2017;3:147:w14401.

10. Gürkan G, Kahraman S. Development of an attitude scale to measure attitudes towards transplantation and donation of preservice teachers. J Baltic Sci Educ 2018;17:6.

11. Vitale, E. Clinical teaching models for nursing practice: a review of literature. Profess Inferm 2014;67:17-125.

12. Villarboito D. L'Italia al terzo posto in Europa per donazioni di organi, AIDO. [Internet]; 2019. Available from: www.ilcosmo.com Accessed: 19 August 2019.

13. Ordin YS, Söylemez BA. Effects of Peer Education on Attitudes Toward Organ Donation in Nursing Students. Transpl Proc 2010;50:10

14. Fontana F, Massari M, Giovannini L, et al. Knowledge and Attitudes Toward Organ Donation in Health Care Undergraduate Students in Italy. Transpl Proc 2017;49:1982-7.

15. Mantecchini L, Paganelli F, Peritore D, et al. Transport of human organs in Italy: location, time, and performances Transplant Proc 2017;49:622-8.

16. Council of Europe. International figures on organ donation and transplantation activity, waiting list and family refusals. Manuale TPM, 2010. [Internet]; 2015; Available from: https://www.edqm.eu/sites/default/files/newsletter_transplant_2015.pdf Accessed: 20 August 2019.

17. Giannini A, Abelli M, Azzoni G, et al.; Working Group on DCD of Italian Society of Anesthesiology, Analgesia and Intensive Care (SIAARTI); Italian Society for Organ Transplantation. Why can't I give you my organs after my heart has stopped beating?" An overview of the main clinical, organisational, ethical and legal issues concerning organ donation after circulatory death in Italy. Minerva Anestesiol 2016;82:359-68.

18. Pretagostini R, Fiaschetti P, Peritore D, et al. Research for optimization in organ donation in a macro-area after federal reform of the Italian health system. Transplant Proc 2012;44:1815-7.

19. Symvoulakis E, Markaki A, Rachiotis G, et al. Organ donation attituted and general self-efficacy: exploratory views from a rural primary care setting. Rural Remote Health 2019; 19:5241. 